\title{
Irrigation Methods and Scheduling in the Delta Region of Mississippi: Current Status and Strategies to Improve Irrigation Efficiency
}

\author{
Hirut Kebede, Daniel K. Fisher, Ruixiu Sui, Krishna N. Reddy \\ Crop Production Systems Research Unit, USDA-ARS, Stoneville, MS, USA \\ Email: hirut.kebede@ars.usda.gov
}

Received 8 July 2014; revised 11 August 2014; accepted 27 August 2014

Copyright (C) 2014 by authors and Scientific Research Publishing Inc.

This work is licensed under the Creative Commons Attribution International License (CC BY). http://creativecommons.org/licenses/by/4.0/

(c) (i) Open Access

\begin{abstract}
Even though annual rainfall is high in the Delta region of Mississippi, only $30 \%$ occurs during the months in which the major crops are produced, making irrigation often necessary to meet crop water needs and to avoid risk of yield and profitability loss. Approximately, $65 \%$ of the farmland in this region is irrigated. The shallow Mississippi River Valley Alluvial Aquifer is the major source of water for irrigation and for aquaculture in the predominant catfish industry. This groundwater is being heavily used as row-crop irrigation has increased tremendously. Water level in this aquifer has declined significantly over the past twenty five years, with overdraft of approximately 370 million cubic meters of water per year. Moreover, the common irrigation practices in the Delta region of Mississippi do not use water efficiently, further depleting the ground water and making irrigation more expensive to producers due to increasing energy prices. Irrigation experts in the region have tested and verified various methods and tools that increase irrigation efficiency. This article presents a review of the current status of the irrigation practices in the Delta region of Mississippi, and the improved methods and tools that are available to increase irrigation efficiency and to reduce energy costs for producers in the region as well as to stop the overdraft of the declining aquifer, ensuring its sustainable use.
\end{abstract}

\section{Keywords}

The Delta Region of Mississippi, Irrigation Efficiency, Irrigation Scheduling, Furrow Irrigation, Crop Water Use 


\section{Introduction}

The Delta region of Mississippi (Figure 1) is agronomically very productive under proper management, having deep alluvial soils with a relatively high annual precipitation $(1100-1500 \mathrm{~mm})$ and 220 to 260 frost-free days per year [1]. The soils have developed over many years of deposition from seasonal flooding of the Mississippi River and its tributaries. Delta soils are nutrient rich, but they vary widely in texture, structure and depth [1] [2]. Approximately 70\% of the yearly rainfall occurs during the months from September to April and this is the main source of water to replenish moisture to the root zone for the beginning of the growing season. Nonetheless, the rest $30 \%$ of the annual rainfall occurs in the months of May, June, July, and August during which the major crops are produced. Figure 2 shows the monthly average rainfall for the years 1960-2013 for Stoneville, MS, which is one of the major weather stations in the Delta region of Mississippi. Due to this variability in rainfall distribution, irrigation is often necessary to meet crop water needs and avoid loss in yield and profitability.

Over $80 \%$ of the crops produced in Mississippi are grown in the Delta [1]. The major crops grown in the Delta region of Mississippi are cotton, soybeans, corn and rice. Nearly 65\% of the Delta farmland is irrigated (Table 1). The shallow Mississippi River Valley Alluvial Aquifer is the main source of groundwater in the Delta for irrigation of crops as well as for filling and maintaining water levels in aquaculture ponds for the catfish industry [1] [3]. The Yazoo Mississippi Delta Joint Water Management District (YMD) annually estimates the total groundwater pumped from the Mississippi River Valley Alluvial Aquifer for various crops grown in the Delta region of Mississippi. According to the YMD report of 2010 (Table 1), approximately 60\% of the cotton, corn and soybean acres, and $100 \%$ of the rice and aquaculture acreage in the Delta were irrigated. Soybeans covered the largest irrigated acreage (53\%) followed by rice (17.5\%), corn (17.2\%), cotton (9.9\%) and aquacul-

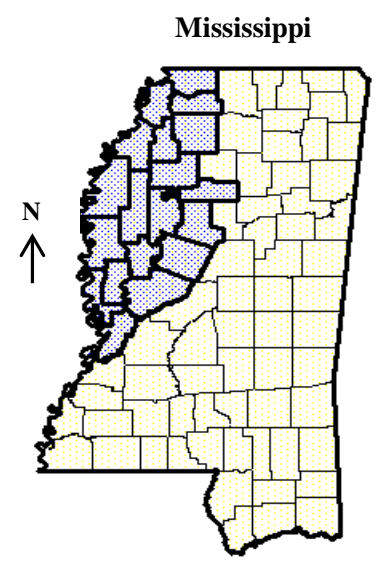

Figure 1. Map of the state of Mississippi showing the location of the Delta region highlighted in blue (latitude/longitude of the Delta region, $32^{\circ}$ to $35^{\circ}$ North and $90^{\circ}$ to $91^{\circ}$ West).

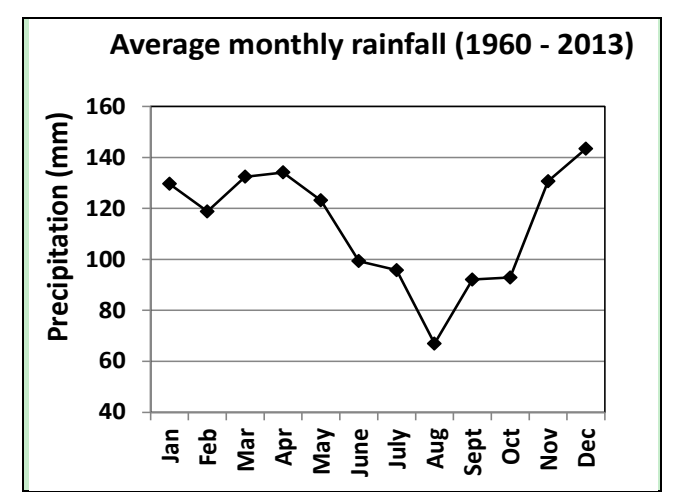

Figure 2. Monthly average rainfall for Stoneville, MS (1960-2013). Source: national climate data center (http://www.ncdc.noaa.gov/). 
Table 1. Estimated groundwater use in the Mississippi Delta from the Mississippi River Valley Alluvial Aquifer in 2010 (data from YMD annual estimates, http://www.ymd.org/).

\begin{tabular}{cccc}
\hline Crops & Total hectares & Estimated irrigated hectares & Estimated water use (ha-m) $^{\mathrm{a}}$ \\
\hline Corn & $215,704(19 \%)^{\mathrm{b}}$ & $122,890(17 \%)$ & $29,978(9 \%)$ \\
Cotton & $121,312(11 \%)$ & $70,457(10 \%)$ & $15,039(5 \%)$ \\
Rice & $124,848(11 \%)$ & $124,848(18 \%)$ & $129,437(41 \%)$ \\
Soybeans & $640,394(57 \%)$ & $379,877(53 \%)$ & $127,419(40 \%)$ \\
Aquaculture & $15,581(2 \%)$ & $15,581(2 \%)$ & $14,253(5 \%)$ \\
Totals & $1,117,839$ & $713,653(65 \%)$ & 316,125 \\
\hline
\end{tabular}

a (ha-m): hectare-meters; ${ }^{\mathrm{b}}$ Percent values in the parenthesis indicate the percentage for each crop out of the total.

ture (2.2\%). Rice, however, with only $17.5 \%$ of the total irrigated acreage, used more water than any other crop. Soybeans and rice used about $80 \%$ of the estimated water usage (Table 1). According to YMD (Figure 3), on average, rice uses about 9.1 Megaliters/hectare (ML/ha) of groundwater, which is about three times that used by corn or soybeans and about six times used by cotton with averages of 2.7, 2.3 and $1.7 \mathrm{ML} / \mathrm{ha}$ for corn, soybeans, and cotton, respectively. As shown in Table 1, these crops and the aquaculture used up about 3.2 billion cubic meters of water from the aquifer in 2010. Water level in this aquifer has declined significantly over the past twenty five years [3]. The overdraft of the aquifer in Mississippi is estimated to be approximately 370 million cubic meters per year and is attributed to the irrigation of over 700,000 hectares of row crops located in the Delta region of Mississippi [3] [4]. The decline is the most prominent from April to October each year when normal crop water demands are intensified by simultaneous dry climatic conditions and the recharge of the aquifer during the remainder of the year has been insufficient to restore water levels [3]. The groundwater is being heavily used for irrigation as the demand continues to grow due to a tremendous increase in the production of row crops [3]. Moreover, the common irrigation practices in the Delta region of Mississippi are inefficient, further depleting the ground water and making irrigation expensive to producers due to increasing energy prices. To reduce water use and stop the decline of the aquifer, various tools and methods that increase irrigation efficiency have been tested and verified by the irrigation experts in the region. This review briefly summarizes the current status of the irrigation practices in the Delta region of Mississippi, and the methods and tools that improve irrigation efficiency in order to reduce energy costs and the overdraft of the aquifer. In this review we have used valuable information obtained from various web sites in addition to the available literature to describe strategies to improve irrigation efficiency.

\section{Irrigation Methods and Improvements in the Delta Region of Mississippi}

\subsection{Current Irrigation Methods}

About $60 \%$ of the cropland in Mississippi is irrigated with furrow and center pivot being the two predominant irrigation systems (Table 2). Furrow irrigation accounts for about $75 \%$ of the irrigated area and the remaining area is irrigated with center pivot (Table 2). In two neighboring states, Arkansas and Louisiana, furrow irrigation accounts for over $80 \%$ with center pivot/sprinkler accounting less than $20 \%$ of the irrigated land. Table 3 (a) shows a summary of the annual survey report from YMD on irrigation methods used for the major crops grown in the Delta region of Mississippi for five consecutive growing seasons (2005-2009). The total number of survey sites reported by YMD under each irrigation method was listed for each crop for the five cropping seasons and the average percentages for each method were calculated. Based on these data, over $85 \%$ of the corn and cotton and about $50 \%$ of the soybean sites, with an average of $75 \%$, were furrow irrigated. The sites under center pivot were only about $10 \%$. The common furrow irrigation practice in the Delta is to pump water using poly-ethylene tubing until water gets to the end of the furrows, but all furrows do not reach the tail-ditch at the same time. This may causes deep percolation losses (over-saturation of the soil profile) and also results in tail-water runoff, wasting water. The rice flooding methods in Mississippi include the straight levee, contour, straight levee with multiple inlets, and zero grade with $45 \%, 30 \%, 20 \%$ and $5 \%$ in coverage, respectively [4]. In the Delta region of Mississippi, about 55\% of the YMD survey sites were irrigated with straight levee, $20 \%$ contour, $12 \%$ straight levee with multiple inlets, and 12\% zero grade methods (Table 3(a)). The straight levee and contour irrigation 


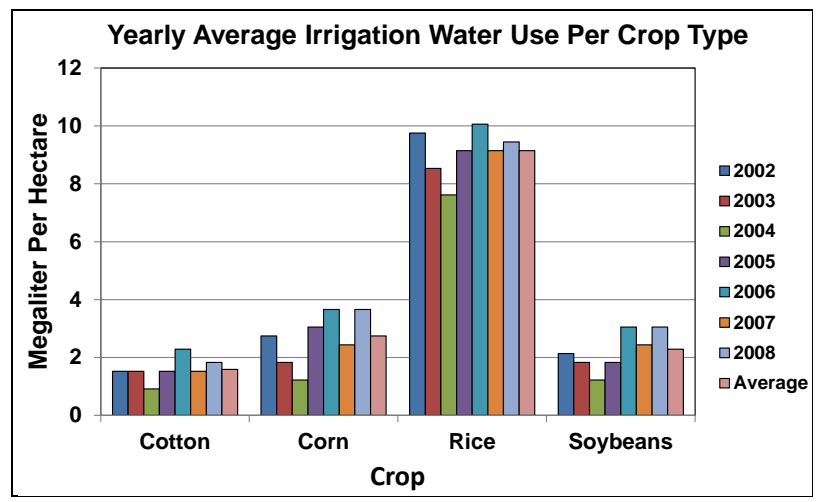

Figure 3. Yearly average water use estimates for rice, corn, soybeans and cotton (Megaliters per hectare) in the Delta region of Mississippi during the 2002-2008 growing seasons (MYD annual estimates, http://www.ymd.org/publications.htm).

Table 2. Irrigated hectarage and irrigation methods (in percentage of hectares under each method) in Mississippi, Arkansas and Louisiana (data from USDA — National Agricultural Statistical Service, 2008).

\begin{tabular}{ccccc}
\hline State & $\begin{array}{c}\text { Total Crop Land } \\
\text { (Hectares) }\end{array}$ & Irrigated (Hectares) & Furrow (\%) & \begin{tabular}{c} 
Irrigation Methods \\
\cline { 3 - 4 }
\end{tabular} \\
Mississippi & $1,016,757$ & $587,469(58 \%)^{\mathrm{a}}$ & 74 & 26 \\
Arkansas & $2,493,748$ & $1,818,448(73 \%)$ & 82 & 18 \\
Louisiana & 839,528 & $377,459(45 \%)$ & 86 & 14 \\
\hline
\end{tabular}

${ }^{a}$ Percent values in the parenthesis show percent of irrigated crop land out of the total crop land.

Table 3. Irrigation methods used for the major crops grown in the Delta region of Mississippi (a), and comparison of water use by each irrigation method (b) in the YMD survey sites during the 2005-2009 growing seasons (data were obtained from YMD annual report, http://www.ymd.org/publications.htm and summarized).

\begin{tabular}{|c|c|c|c|c|c|c|}
\hline Crop type & Furrow & Center Pivot & Contour & Straight Levee & Multiple Inlet & Zero-Grade \\
\hline \multicolumn{7}{|c|}{ (a) Sites under Each Method } \\
\hline Corn & $114(92 \%)^{\mathrm{a}}$ & $10(8 \%)$ & & & & \\
\hline Cotton & 75 (86\%) & $12(14 \%)$ & & & & \\
\hline Soybean & $120(48 \%)$ & $20(8 \%)$ & $23(9 \%)$ & $83(34 \%)$ & & $2(1 \%)$ \\
\hline Rice & & & $31(20 \%)$ & $88(56 \%)$ & $18(12 \%)$ & $18(12 \%)$ \\
\hline \multicolumn{7}{|c|}{ (b) Water Use (Megaliters per Hectare) } \\
\hline Corn & 3.4 & 1.5 & & & & \\
\hline Cotton & 1.8 & 1.5 & & & & \\
\hline Soybeans & 2.4 & 1.8 & 2.7 & 2.1 & & \\
\hline Rice & & & 11.0 & 9.8 & 8.5 & 5.8 \\
\hline
\end{tabular}

${ }^{\mathrm{a}}$ Number of YMD survey sites under each irrigation method (percentage of sites under each irrigation method is shown in parenthesis).

or flooding methods utilize a well or riser in the highest-elevation portion of the field and water spills into lower paddies as the upper paddies are filled [5] [6]. During the time of flooding, an increasingly larger area is covered with water until the entire area within the levees is flooded [5] [6]. When the floodwaters naturally subside and when saturated mud is exposed in the upper half of the paddy, water is pumped back to a full-flood depth of about four inches [7]. These conventional furrow and rice flooding practices do not use water efficiently. 


\subsection{Improvements in Irrigation Methods}

The YMD reports yearly comparison of water use by different irrigation methods in the Delta region of Mississippi (http://www.ymd.org/publications.htm). Table 3(b) shows water use by the different irrigation methods for the same crops and survey sites shown in Table 3(a) (averaged over five years, 2005-2009). In the survey sites, an average of 3.4 ML/ha was used in corn with the furrow irrigation method, whereas only $1.5 \mathrm{ML} / \mathrm{ha}$ was used by center pivot, a savings of more than $50 \%$ of irrigation water compared with furrow irrigation. Cotton used 1.8 and $1.5 \mathrm{ML} /$ ha of water on the average under furrow and center pivot, respectively, which is a savings of about $15 \%$ water. In soybean, the center pivot reduced water use from 2.4 to $1.8 \mathrm{ML} / \mathrm{ha}$, saving about $25 \%$ water. Nonetheless, center pivots were used in only $10 \%$ of the sites for these three crops (Table 3(a)). In soybean, in addition to the furrow and center pivot methods, contour and straight levee methods are also used. Furthermore, the contour method used the highest irrigation water out of all the methods for soybean as well as for rice. The zero-grade method saved about $50 \%$ water in rice $(5.8 \mathrm{ML} / \mathrm{ha})$ followed by the multiple inlet method with a savings of about $20 \%$ (8.5 ML/ha) as compared to the contour method (11 ML/ha) (Table 3(b)). However, only about $12 \%$ of the sites used these two water use efficient methods (Table 3(a)). Studies on energy saving by irrigation experts at Mississippi State University showed that the zero-grade irrigation method, with nearly 50\% water reduction, was estimated to save producers up to 160 liters of diesel per hectare, which in terms of money could be a saving of about $\$ 136$ US dollars per hectare at a price of $\$ 0.85 /$ liter compared with the contour method [7]. The estimated energy savings for the straight levee with multiple inlets was about 85 liters/ha which would be about \$72/ha compared with the contour method [7]. A recent investigation by Mississippi State University researchers and rice growers in Mississippi showed that intermittent flooding, which maintains a lessthan-full flood, maximizes rainfall capture and avoids run off from completely filled paddies, thus, reducing water and energy use [4] [7]. They also showed that combining intermittent flooding with multiple-inlet irrigation can improve efficiency of the multiple-inlet method by about $30 \%$, which makes the average water use close to that of zero-grade rice fields [4] [7]. In this improved method, instead of pumping water to maintain full paddies, a pumping cycle can be established by turning the well on every five to seven days, thus saving water and energy. Implementation of the water efficient irrigation practices in rice production represent a promising opportunity to generate groundwater savings where savings of only 3000 cubic meters per hectare could save the aquifer nearly 310 million cubic meters of water per year [4] [7] [8]. This savings would approach the average overdraft and help to bring groundwater withdrawals closer to the recharge rate of the aquifer [8].

The furrow irrigation method is the most dominant in row crop production in the Delta region of Mississippi and Mississippi as a whole (Table 2 and Table 3(a)). Various tools and methods employed in other regions have been tested in the Delta to increase the efficiency of the furrow irrigation as well as other surface irrigation methods. Efficiency of furrow irrigation can be improved using computerized hole-selection softwares such as the Pipe Hole and Universal Crown Evaluation Tool (PHAUCET) or the Delta Plastic Pipe Planner

(http://www.pipeplanner.com/) [4] [9]. The PHAUCET is a free software program developed by engineers with the US Department of Agriculture's National Resources Conservation Service (NRCS) in Missouri [9] [10]. It uses engineering equations to calculate pipe pressure and flow rates for each watered furrow, and can compute proper hole-size designs for fields that vary in layout. Researchers in Arkansas, Mississippi and Louisiana have shown that PHAUCET reduces water, fuel and irrigation usage by 20 percent versus conventional irrigation sets in regular-shaped fields, and in irregular-shaped fields, could reduce water use as much as 50\% [7] [9] [11]. Furrow irrigation efficiency is further improved when the computerized hole-selection programs are used in conjunction with surge valves [11]. Conventional furrow irrigation sets apply water continuously while surge flow intermittently applies water to the irrigated furrows and increases efficiency by distributing water more evenly across a field and reducing both water loss to deep percolation and runoff [9] [11]. With furrow irrigation accounting for $85 \%$ of the corn and cotton and $50 \%$ of the soybean farms, increase in efficiency of furrow irrigation through use of these tools could bring huge savings in water and energy usage in the Mississippi Delta.

Other measures can also be employed to save water in the different irrigation methods. Tailwater recovery, which involves collecting water that runs off from surface-irrigated fields and reusing it for irrigation, improves overall irrigation efficiency [12]. Installation of a timer helps to automatically or remotely turn the pumps off, which might otherwise be pumping more water than is needed by the plant, particularly at night. Flow meters could also help save water by allowing producers to keep track of water applied in each field.

The template is used to format your paper and style the text. All margins, column widths, line spaces, and text 
fonts are prescribed; please do not alter them. You may note peculiarities. For example, the head margin in this template measures proportionately more than is customary. This measurement and others are deliberate, using specifications that anticipate your paper as one part of the entire journals, and not as an independent document. Please do not revise any of the current designations.

\section{Irrigation Scheduling}

\subsection{Irrigation Scheduling Methods}

The purpose of irrigation scheduling is to determine the timing and the amount of water to be applied based upon the crop's water needs, soil water storage capacity and climatic conditions. Irrigation scheduling methods, in general, can be classified as plant-, soil-, or climate-based, or combinations [13]. The most common methods use either daily crop evapotranspiration (ET) estimates as crop water use, or measurements of soil moisture status, or a combination of these two methods, to determine when and how much irrigation water needs to be applied [14] [15]. The different tools available for irrigation scheduling include soil moisture sensors, in-field weather stations, crop water use estimators, daily soil water balance checkbook worksheets and computerized daily soil water balance programs [15].

Crop water use is the amount of water given up to the atmosphere by transpiration through plant leaves and evaporation from the soil and plant surfaces, referred as evapotranspiration or ET [16]. Daily crop water use changes throughout the growing season depending on the stage of crop development and weather conditions. Climatic parameters having a major effect on a crop's daily water use include maximum and minimum temperatures, solar radiation, humidity, and wind. Estimation of evapotranspiration for specific crops $\left(\mathrm{ET}_{\mathrm{c}}\right)$ is important for irrigation scheduling and agricultural water management. Irrigation is required when $\mathrm{ET}_{\mathrm{c}}$ (crop water demand) exceeds the supply of water from soil water and precipitation. Crop evapotranspiration for a specific crop can be estimated by multiplying the reference evapotranspiration (ET ( $_{\mathrm{O}}$ by a crop specific crop coefficient $\left(\mathrm{K}_{\mathrm{c}}\right)$ [17]. Reference evapotranspiration is an estimate of the amount of water lost from a theoretical reference surface, usually a well-watered field of grass, and is a measure of the evaporative power of the environment. Crop coefficient is an adjustment factor that mainly depends mainly on crop type and its growth stage. Using several years of weather data and crop water use data, $K_{c}$ can be estimated and a specific $K_{c}$ curve can be developed that shows the water requirement of the specific crop. However, developing $\mathrm{K}_{\mathrm{c}}$ for a specific crop in the Mississippi Delta and the humid mid-south as a whole has been difficult due to highly variable daily evaporative demand [18]. In a four-year study (2003-2006) of cotton in Stoneville, MS, seasonal water-use patterns varied among growing seasons due to highly variable environmental and crop-growth conditions, making it difficult to develop a crop-coefficient for the Mississippi Delta growing conditions [18].

Irrigation scheduling is complex in the humid mid-southern US than in the drier environments of the US due to highly variable climatological conditions such as fluctuating temperature and rainfall caused by the movement of weather fronts which make the daily evaporative demand highly variable, and these weather conditions vary from year to year and even within a year affecting crop-growth and crop-water use [18]-[20]. Additionally, the soils in this region are highly variable, and sometimes exhibiting restrictive layers at shallow depths which can reduce the water storage capacity of the soil [1] [19] [20]. Thus, this variability must be accounted for in irrigation scheduling. While many irrigation scheduling methods have been developed for dry climates, few tools are available for humid, high rainfall areas [20].

The most common irrigation scheduling method is the water balance, or checkbook, method which can range from a simple spreadsheet record keeping to sophisticated web-based computer models that require weather and other information [14] [15]. In the water balance method, soil water is balanced by taking account of the amount of water that leaves as crop evapotranspiration $\left(\mathrm{ET}_{\mathrm{c}}\right)$ and water that enters the soil reservoir as rain or irrigation. By keeping records of these transactions, it is possible to estimate how much water is in the soil reservoir at any time. Daily ET estimates are needed for the water balance method to update the soil water deficit balance. There are a variety of equations that are used to calculate reference ET, ranging from simple empirical models to sophisticated physically based energy- and mass-transfer models. While the FAO-56 Penman-Monteith method is the de facto standard, other methods, such as the Modified-Penman, Jensen-Haise, Hargreaves, Turc, and ASCE Standardized Reference equation are also in use [13] [21]-[23], with various versions of the Penman-Monteith method being the most widely used [13] [24] [25]. Daily crop water use or $\mathrm{ET}_{\mathrm{C}}$ can also be estimated using tools such as evaporation pans, atmometers (atmosphere meters), or crop water use (ET) tables which are usually pro- 
vided by county or state extension programs. These simpler tools are used to estimate reference ET, which is then adjusted to provide estimates of $\mathrm{ET}_{\mathrm{c}}$ using device-specific crop coefficient functions [13] [26].

Soil-based methods of irrigation scheduling includes monitoring soil moisture using sensors and the "feel method", which involves an estimate of soil moisture by feeling the soil [27]-[29]. There are two groups of soil moisture sensors, soil water tension-based sensors (tensiometers and granular matrix sensors), and soil water content-based sensors (capacitance, neutron probe and gravimetric) [27]. Soil moisture sensor readings can be used to determine how much water is available for the crop, when to start irrigating, and how much water to apply [27] [29]. The sensors also show depth of wetting, depth of extraction by roots and adequacy of wetting [29]. When sensors indicate that remaining soil moisture level reaches a critically low value, irrigation is applied. Monitoring sensor measurements can be used as a stand-alone method or in combination with the ET method for irrigation scheduling [30]. The soil feel method, which is a low cost method, has been used for many years by researchers and growers [28] [31]. By squeezing the soil between the thumb and forefinger or by squeezing the soil in the palm of a hand, a fairly accurate estimate of soil moisture can be determined by someone with experience. This method is still being recommended by extension specialists to growers in different parts of the country [28] [31] [32].

\subsection{Irrigation Scheduling in the Delta Region of Mississippi}

Crop producers in the Mississippi Delta and in Mississippi as a whole primarily determine to irrigate their fields using a subjective plant-based method, which is visually observing the condition of the crop (USDA-NASS, 2008, Table 4). Their second choice of irrigation scheduling method was the soil feel method (Table 4). On average, about $8 \%$ of producers used a personal calendar schedule, approximately $10 \%$, based their irrigation decisions on daily crop evapotranspiration (ET). These methods are very similar to those used by producers in Arkansas, Louisiana and Tennessee except that in Mississippi, ET based scheduling was slightly higher and the personal calendar scheduling was slightly lower than in the other states (Table 4). The soil moisture sensor based irrigation scheduling accounted for less than 5\% of the farms in Mississippi, Arkansas, Louisiana and Tennessee, on the average. The percentages for the irrigation scheduling methods in these four states was not very different from the national average as shown in Table 4. The national average for the method using visual observation of crop condition is about $44 \%$ (ranging 32\% - 57\%) and the soil feel method is about 25\% (ranging $13 \%$ - 42\%). Even though many computer based and web-based irrigation scheduling tools are available these data show that a very small percentage of the farms use these scientific irrigation scheduling methods.

The scientific irrigation scheduling method available to the Mississippi Delta producers has been the Arkansas Irrigation Scheduler, developed by the University of Arkansas for the humid Mid-South [19]. This Scheduler has been used by producers in Arkansas and the surrounding states for over twenty years [6]. However, based on

Table 4. Irrigation scheduling methods used on farms in Mississippi, Arkansas and Louisiana (data from USDA-NASS, 2008).

\begin{tabular}{|c|c|c|c|c|}
\hline \multirow{2}{*}{ Method } & Mississippi & Arkansas & Louisiana & National average \\
\hline & \multicolumn{4}{|c|}{ Farms (\%) } \\
\hline Condition of crop (visual) & 47.2 & 48.8 & 56.7 & 43.9 \\
\hline Feel of soil & 23.9 & 20.6 & 16.5 & 24.8 \\
\hline Daily crop evapotranspiration (ET) & 9.6 & 3.8 & 2.2 & 3.4 \\
\hline Personal calendar schedule & 7.9 & 10.8 & 13.7 & 10.1 \\
\hline Soil moisture sensing device & 4.6 & 3.4 & 1.9 & 4.4 \\
\hline When neighbors irrigate & 2.2 & 2.5 & 1.2 & 3.0 \\
\hline Commercial or government scheduling device & 1.4 & 3.4 & 1.8 & 2.7 \\
\hline Plant moisture sensing device & 0.1 & 1.3 & 1.1 & 0.8 \\
\hline Computer simulation models & 0.2 & 0.5 & 0.3 & 0.6 \\
\hline Scheduled by water delivery organization & 0.1 & 0.3 & 0.7 & 3.6 \\
\hline Other & 3.0 & 4.7 & 3.9 & 4.6 \\
\hline
\end{tabular}


the data from USDA-NASS (Table 4), this scheduler may have been used only by a very small number of producers in Mississippi and the surrounding states. A computer based irrigation scheduling tool, the Mississippi Irrigation Scheduling Tool (MIST), is being developed by the USDA-ARS and Mississippi State University researchers [33] [34]. An estimate of crop water use is made using a modified Penman Monteith method [20] to calculate daily evapotranspiration. This checkbook method maintains the water balance of the soil, adding water from rainfall or irrigation, and subtracting water used by the crop or evaporated from the soil. The need for irrigation is indicated when the soil water available to the plant falls below that which is required for the crop growth [34]. The MIST has been implemented in a web interface, allowing producers to access the information from anywhere via computers, tablets or smart phones [33]. The system relies on national databases for automated integration with a water balance model. However, due to the high degree of spatial variability in precipitation in Mississippi, information extracted from the nearest publicly available weather station may not represent the actual precipitation on a particular field which can affect the water balance calculations. Incorporating automated data from the National Weather Service (NWS) spatially gridded radar-estimated precipitation was tested to determine if it could improve the issue with spatial rainfall variability [35]. Comparison between rainfall from publicly available stations and spatially gridded radar precipitation estimates showed some discrepancies [36]. According to Sassenrath et al. [34], given the Delta's local practice of irrigating to replace full evapotranspiration, use of the NWS daily precipitation analysis data as input for a daily irrigation scheduler was judged not only acceptable, but also preferable to other sources of daily precipitation data. However, data from an on-site rain gauge would be the most reliable measurement of daily precipitation.

While the MIST and the Arkansas Irrigation Scheduler both use a water balance scheduling method the Arkansas Irrigation Scheduler requires daily values of air temperature and effective precipitation as input by the producer [37]. The MIST, on the other hand, automatically extracts weather data from online weather data sources [31] [33]. Entering daily precipitation values has the advantage of solving the issue of spatial variability in precipitation as encountered in the MIST. Crop evapotranspiration in these systems is calculated using different equations and built-in crop-coefficient functions, then the soil-water deficit is updated, and the current soil-water deficit and a projection of the deficit for the next few days are output. The user then decides whether to irrigate based on an allowable deficit level chosen by the user, with guidance from the program based on soil type, crop, and irrigation system [18].

Currently, soil moisture sensors are being promoted as a valuable irrigation scheduling tool to producers in the Delta region of Mississippi by the Mississippi State University irrigation extension specialists [38]. Soil moisture sensors placed at different soil depths allow the producer to determine how much moisture the soil has available to plants and to schedule irrigation in advance. Use of soil moisture sensors in combination with computerized hole-selection programs and surge valves is recommended by the experts to be the most water use efficient surface irrigation practice at present for producers in the Mississippi Delta [8] [10] [38].

\section{Other Considerations in Increasing Irrigation Efficiency in the Delta Region of Mississippi}

Many irrigation scheduling tools in the other parts of the US use different forms of the water balance method in which crop specific ET values are estimated from the daily air temperatures provided by the producer or online based on nearby weather station data [15] [39] [40]. Precipitation from a rain gauge or a local weather station, and in some cases soil moisture sensor data, is required to be entered by the producer. An alternative for ET estimates is an atmometer. An atmometer is designed to simulate ET from a plant canopy in a way that agrees closely with a plant's resistance to ET and it closely matches the values calculated from weather station data [26]. It can be located in a grower's field, making it especially useful for areas without nearby weather stations or for people who do not have ready access to this information and can help to schedule irrigations for any field within several miles [26]. Atmometers have shown close agreement to the modified Penman method ET (similar to method used in MIST) in some studies [41]-[43]. An atmometer or ET Gauge is being evaluated by University of Arkansas extension specialists and county agents for irrigation scheduling. ET Gauge sheets have been developed for Arkansas based on crop growth stage for corn and soybean grown to help Arkansas producers set their atmometers [44]. In Nebraska, modified atmometers $\left(\mathrm{ET}_{\text {gage }}\right)$ together with watermark soil moisture sensors are recommended to producers as cost-effective tools for irrigation scheduling [45]. Since the Mississippi Delta has not only humid and highly variable weather, but also highly variable soils, irrigation scheduling with a com- 
bination of an atmometer and soil moisture sensors might be an alternative if tested and proven to work in this environment.

An investigation was conducted to find alternative methods of estimating ET in humid environments with limited weather data [46]. Three ET estimation methods, which are recommended for use when weather data are limited, the FAO-56 reduced set, the Turc and the Hargreaves methods, were compared with the standard FAO56 method under the Delta weather conditions. When the weather data were limited only to air temperature and solar radiation, the Turc method, originally developed with air temperature and solar radiation as inputs, was found to provide better estimates of the FAO-56 method compared with the FAO-56 reduced and the Hargreaves methods [46]. The Turc method has consistently performed well when tested under other humid environments [47] [48]. This method would be of use in the Delta region of Mississippi if the complete set of weather data for the FAO-56 method was unavailable, or if a computationally simpler method was desired [46].

Deficit irrigation (DI) is a strategy used in water-limited environments to reduce agricultural water use. The classic DI strategy implies that water is supplied at levels below full crop evapotranspiration throughout the season [49] [50]. Deficit irrigation deliberately allows crops to sustain some degree of water deficit with some yield reduction and a significant reduction of irrigation water applied [49]-[51]. Regulated Deficit Irrigation (RDI) is a modified DI in which water deficit is applied at certain periods of the growth stages of a crop to save water but still maintain yield [49]-[52]. To address the issue of increasing production costs and restricted water use by producers arising from decline in groundwater levels, experts at Mississippi State University have been conducting some RDI studies in soybeans [53]. They tried to determine if, relative to the common soybean practices of the Mississippi Delta, an irrigation event can be omitted while maintaining yield and profitability. The study indicated that there is potential to eliminate at least one irrigation event without adversely affecting yield or profitability [53]. Similar studies for the major crops in the Delta of Mississippi could also help producers in cutting energy costs and saving groundwater. The DI strategy, in which irrigation is reduced below the evapotranspiration demand of the crop throughout the growing season, may not be acceptable in the Delta now with other options still available to cut down water use and energy costs. However, it may be worthwhile to start thinking about it now to lay a strategy for the long term considering the rapidly growing demand for the groundwater due to the tremendous increase in water use for row crops in the Delta. Moreover, weather changes and the increases in demand for supplemental irrigation may still require a more restricted groundwater use, making DI an option.

\section{Summary}

In this review, the current status of the irrigation practices used by producers in the Delta region of Mississippi, and the improved methods and tools that can efficiently utilize the groundwater have been discussed. The strategies that are currently recommended by irrigation experts in the region to improve irrigation efficiency in the Delta region of Mississippi are summarized below.

- Furrow irrigation using computerized hole-selection programs in conjunction with surge valves;

- Multiple inlet irrigation with intermittent flooding for rice;

- Zero-grade irrigation for flood-irrigated rice and soybeans;

- Soil moisture sensors recommended as the primary tools for irrigation scheduling while a web-based irrigation management tool, the MIST, is being developed;

- Tailwater recovery from surface-irrigated fields and reuse for irrigation;

- Center pivots-water savings of about $50 \%$ in corn, and $15 \%$ - $25 \%$ in cotton and soybeans as compared to furrow irrigation.

Widespread adoption of these efficient irrigation methods and tools together with irrigation scheduling using soil moisture sensors can tremendously reduce water use and fuel energy expenses for producers in the Delta while reducing the current overdraft of the Mississippi River Valley Alluvial Aquifer and ensuring its sustainable use.

\section{Disclaimer}

Mention of a trade name or specific equipment in this publication is solely for the purpose of providing specific information and does not imply recommendation or endorsement by the US Department of Agriculture. 


\section{References}

[1] Snipes, C.E., Nichols, S.P., Poston, D.H., Walker, T.W., Evans, L.P. and Robinson, H.R. (2005) Current Agricultural Practices of the Mississippi Delta Mississippi. Agricultural \& Forestry Experiment Station, Bulletin 1143.

[2] USDA-Natural Resources Conservation Service, Soil Survey of Leflore County, Mississippi, Wit, E. and McClure, J. (2004) Statistics for Microarrays: Design, Analysis, and Inference. 5th Edition, John Wiley \& Sons Ltd., Chichester.

[3] Wax, C.L., Pote, J.W. and Merrell, T.L. (2008) Climatological and Cultural Influences on Annual Groundwater Decline in the Mississippi Shallow Alluvial Aquifer. $38^{\text {th }}$ Annual Mississippi Water Resources Research Conference, Jackson, April 2008.

[4] Massey, J. (2010) Water-Conserving Irrigation Systems for Furrow and Flood Irrigated Crops in the Mississippi Delta. Final Report, Mississippi Water Resources Research Institute (MWRRI).

[5] Heathrely, G.L. (1999) Soybean Irrigation. In: Heatherly, L.G. and Hodges, H.F., Eds., Soybean Production in the Midsouth, CRC Press, Boca Raton, 119-142.

[6] Vories, E.D., Tacker, P.L. and Hogan, R. (2005) Multiple Inlet Approach to Reduce Water Requirement for Rice Production. Applied Engineering in Agriculture, 21, 611-616. http://dx.doi.org/10.13031/2013.18571

[7] Massey, J. (2011) Water and Energy Conservation Practices for Mississippi Rice Production. http://www.mississippi-crops.com/wp-content/uploads/2011/11/Irrigation-Methods-and-Ways-to-Save-Money-Compat ibility-Mode.pdf

[8] Powers, S. (2007) Agricultural Water Use in the Mississippi Delta, Yazoo Mississippi Delta Joint Water Management District. http://www.ymd.org/publications.htm

[9] Ray, R. (2013) MSU Pushes RISER Plan for Efficient Crop Irrigation. Mississippi Agricultural News, Mississippi Agricultural and Forestry Experiment Station, Mississippi State University.

[10] University of Arkansas, Cooperative Extension Service Irrigation Scheduling: Irrigation for Agriculture in Arkansas. http://www.uaex.edu/environment-nature/water/irrigation.aspx

[11] Krutz, L.J. (2013) Improving Furrow Irrigation Efficiency. Annual Report, Mississippi Soybean Promotion Board. http://mssoy.org/wp-content/uploads/2014/05/54-2013-ANN-REP-FINAL.pdf

[12] Heatherly, L. (2014) Conserving Water Goal of Sustainable Irrigation Project in Mississippi. Delta Farm Press. http://deltafarmpress.com/management/conserving-water-goal-sustainable-irrigation-project-mississippi

[13] Martin, E.C. (2009) Methods of Measuring for Irrigation Scheduling-When. Arizona Cooperative Extension. The University of Arizona, Tucson, Arizona Water Series No. 30.

[14] Harrison, K. (2012) Factors to Consider in Selecting a Farm Irrigation System. University of Georgia Cooperative Extension, Athens, Bulletin 882.

[15] Wright, J. (2002) Irrigation Scheduling Checkbook Method. University of Minnesota Extension. http://www.extension.umn.edu/agriculture/water/irrigation-scheduling-checkbook-method/

[16] Andales, A.A., Chavez, J.L. and Bauder, T.A. (2011) Irrigation Scheduling: The Water Balance Approach. Colorado State University Extension, Fort Collins, Fact Sheet \#4.707.

[17] Ministry of Agriculture (2001) Crop Coefficients for Use in Irrigation Scheduling. Water Conservation Factsheet, Order No. 577.100-5. Ministry of Agriculture, British Columbia.

[18] Fisher, D.K. (2012) Cotton Water Requirement in the Humid Areas. Cotton Irrigation Management for Humid Regions. Cotton Incorporated. http://www.cottoninc.com/fiber/AgriculturalDisciplines/Engineering/Irrigation-Management/cotton-irrigation-web.pdf

[19] Cahoon, J.J., Ferguson, D.E. and Tacker, P. (1990) A Microcomputer-Based Irrigation Scheduler for the Humid Mid-South Region. Applied Engineering in Agriculture, 6, 289-295. http://dx.doi.org/10.13031/2013.26384

[20] Vories, E.D. and Evett, S.R. (2010) Irrigation Research Needs in the USA Mid-South and Southeast, Humid and Sub Humid Regions. In: Decennial National Irrigation Symposium, 5th National Decennial Irrigation Conference, Phoenix, Arizona, 5-8 December 2010, IRR10-8679.

[21] The Environmental and Water Resources Institute of the American Society of Civil Engineers (2005) ASCE Standardized Reference Evapotranspiration Equation. Final Report.

[22] Allen, R.G., Pereira, L.S., Raes, D. and Smith, M. (1998) Crop Evapotranspiration: Guidelines for Computing Crop Water Requirements. United Nations Food and Agriculture Organization, Irrigation and Drainage, Rome, Paper 56.

[23] McMahon, T.E., Peel, M.C., Lowe, L., Srikanthan, R. and McVicar, T.R. (2013) Estimating Actual, Potential, Reference Crop and Pan Evaporation Using Standard Meteorological Data: A Pragmatic Synthesis. Hydrology and Earth System Sciences, 17, 1331-1363. http://dx.doi.org/10.5194/hess-17-1331-2013

[24] Davie, T. (2008) Fundamentals of Hydrology. 2nd Edition, Routledge, New York. 
[25] Bos, M.G., Kselik, R.A.L., Allen, R.G. and Molden, D. (2009) Water Requirements for Irrigation and the Environment. Springer Science + Business Media B.V., Berlin.

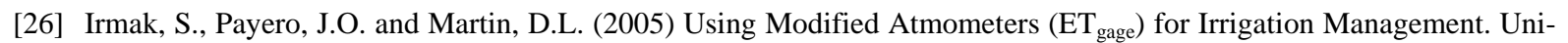
versity of Nebraska-Lincoln Extension, Institute of Agricultural and Natural Resources, Lincoln, G1579.

[27] Peters, R.T. Practical Use of Soil Moisture Sensors for Irrigation Scheduling. Irrigation in the Pacific Northwest. http://irrigation.wsu.edu/index.php

[28] USDA-NRCS (1998) Estimating Soil Moisture by Feel and Appearance. Program Aid Number 1619, Montana.

[29] Hanson, B.R., Orloff, S. and Peters, D. (2000) Monitoring Soil Moisture Helps Refine Irrigation Management. California Agriculture, 54, 38-42. http://dx.doi.org/10.3733/ca.v054n03p38

[30] Ramos, C., Intrigliolo, D.D. and Thompson, R.B. (2011) Global Change Challenges for Horticultural Systems. In: Araus, J.L. and Slafer, G.A., Eds., Crop Stress Management and Global Climate Change, Cabi International, London, 58-69.

[31] Schneekloth, J., Bauder, T., Broner, I. and Waskom, R. (2014) Measure of Soil Moisture. Colorado State University Extension. http://www.ext.colostate.edu/drought/soilmoist.html

[32] Sheffield, R.E. and Weindorf, D.C. (2008) Irrigation Scheduling Made Easy: Irrigation Scheduling, Using the "Look and Feel” Method. Louisiana State University Agricultural Center, Baton Rouge, Pub. \# 3070.

[33] Sassenrath, G.F., Schmidt, A.M., Schneider, J.M., Tagert, M.L., Corbitt, J.Q., van Riessen, H., Crumpton, J., Rice, B., Thornton, R., Prabhu, R., Pote, J. and Wax, C. (2013) Development of the Mississippi Irrigation Scheduling ToolMIST. ASABE Annual International Meeting, Kansas City, 21-24 July 2013, Paper Number: 131619807.

[34] Sassenrath, G.F., Schneider, J.M., Schmidt, A.M., Corbitt, J., Halloran, J.M. and Prabhu, R. (2013) Testing Gridded NWS 1-Day Observed Precipitation Analysis in a Daily Irrigation Scheduler. Agricultural Sciences, 4, 621-627. http://dx.doi.org/10.4236/as.2013.412083

[35] Thornton, R., Sassenrath, G., Schneider, J., Corbitt, J., Schmidt, A., Crumpton, J., Rice, B., van Riessen, H. and Prabhu, R. (2013) Can National Weather Service Spatially Gridded Radar Precipitation Estimates Be Used to Overcome Spatial Variability in Mississippi Precipitation Measurements? Mississippi Water Resources Conference, Jackson, 2-3 April 2013.

[36] Tagert, M.L. (2013) On-Farm Validation of the Mississippi Irrigation Scheduler Tool (MIST) for Corn Production Systems. Progress Report, Mississippi Corn Promotion Board.

[37] University of Arkansas Cooperative Extension Service, the Arkansas Online Irrigation Scheduler. Irrigation for Agriculture in Arkansas. http://www.uaex.edu/environment-nature/water/irrigation.aspx

[38] Coblentz, B. (2013) Moisture Sensors Are Key Part of Efficient Irrigation. Mississippi Agricultural News, Mississippi Agricultural and Forestry Experiment Station, Mississippi State University.

[39] Evans, R., Cassel, D.K. and Sneed, R.E. (1996) Soil, Water and Crop Characteristics Important to Irrigation Scheduling. North Carolina Cooperative Extension Service, Raleigh.

[40] Kranz, W.L., Irmak, S., Simon, J., van Donk, C., Yonts, D.D. and Martin, L. (2008) Irrigation Management for Corn. University of Nebraska-Lincoln Extension Publications, Lincoln.

[41] Alam, M. and Trooien, T.P. (2001) Estimating Reference Evapotranspiration with an Atmometer. Applied Engineering in Agriculture, 17, 153-158. http://dx.doi.org/10.13031/2013.5458

[42] Broner, I. and Law, R.A.P. (1991) Evaluation of a Modified Atmometer for Estimating Reference ET. Irrigation Science, 12, 21-26. http://dx.doi.org/10.1007/BF00190705

[43] Berrada, A., Hotten, T.M., Cardon, G.E. and Broner, I. (2001) Assessment of Irrigation Water Management and Demonstration of Irrigation Scheduling Tools in the Full Service Area of the Dolores Project: 1996-2000. Part II-B: Evaluation of the ETgage Atmometer. Technical Report, Southwestern Colorado Research Center, Agricultural Extension Station, Colorado State University, Fort Collins.

[44] University of Arkansas Cooperative Extension Service. Irrigation Scheduling. Irrigation for Agriculture in Arkansas. http://www.uaex.edu/environment-nature/water/irrigation.aspx

[45] Burr, C., Nyugren, A. and Zoubek, G. (2014) Cost-Effective Tools to Improve Irrigation Efficiency. University of Nebraska-Lincoln-CropWatch. http://cropwatch.unl.edu/archive/-/asset publisher/VHeSpfv0Agju/content/2-cost-effective-tools-to-improve-irrigationefficiency

[46] Fisher, D.K. and Pringle III, H.C. (2013) Evaluation of Alternative Methods for Estimating Reference Evapotranspiration. Agricultural Sciences, 4, 51-60. http://dx.doi.org/10.4236/as.2013.48A008

[47] Trajkovic, S. and Kolakovic, S. (2009) Evaluation of Reference Evapotranspiration Equations under Humid Conditions. Water Resources Management, 23, 3057-3067. http://dx.doi.org/10.1007/s11269-009-9423-4 
[48] Turc, L. (1961) Water Requirements Assessment of Irrigation, Potential Evapotranspiration: Simplified and Updated Climatic Formula. Annales Agronomiques, 12, 13-49.

[49] Costa, J.M., Ortuño, M.F. and Chaves, M.M. (2007) Deficit Irrigation as a Strategy to Save Water: Physiology and Potential Application to Horticulture. Journal of Integrative Plant Biology, 49, 1421-1434. http://dx.doi.org/10.1111/j.1672-9072.2007.00556.x

[50] Rowland, D.L., Fairclotha, W.H., Payton, P., Tissue, D., Jason, T., Ferrell, A., Sorensen, R.B. and Butts, C.L. (2012) Primed Acclimation of Cultivated Peanut (Arachis hypogaea L.) through the Use of Deficit Irrigation Timed to Crop Developmental Periods. Agricultural Water Management, 113, 85-95. http://dx.doi.org/10.1016/j.agwat.2012.06.023

[51] Fereres, E. and Soriano, M.A. (2007) Deficit Irrigation for Reducing Agricultural Water Use. Journal of Experimental Botany, 58, 147-159. http://dx.doi.org/10.1093/jxb/erl165

[52] Geerts, S. and Raes, D. (2009) Deficit Irrigation as an On-Farm Strategy to Maximize Crop Water Productivity in Dry Areas. Agricultural Water Management, 96, 1275-1284. http://dx.doi.org/10.1016/j.agwat.2009.04.009

[53] Krutz, L.J. (2013) Developing Profitable Deficit Irrigation Soybean Production Systems. Annual Report, Mississippi Soybean Promotion Board. http://mssoy.org/wp-content/uploads/2014/06/53-2013-ANN-REP-FINAL.pdf 
Scientific Research Publishing (SCIRP) is one of the largest Open Access journal publishers. It is currently publishing more than 200 open access, online, peer-reviewed journals covering a wide range of academic disciplines. SCIRP serves the worldwide academic communities and contributes to the progress and application of science with its publication.

Other selected journals from SCIRP are listed as below. Submit your manuscript to us via either submit@scirp.org or Online Submission Portal.
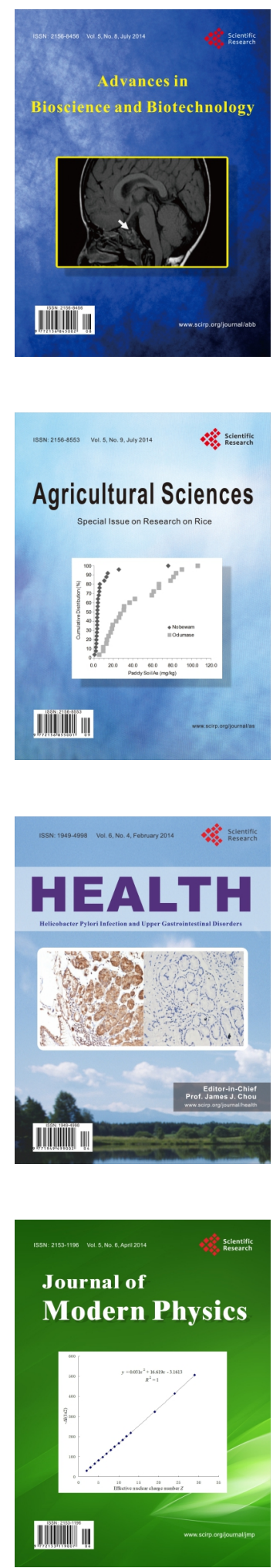
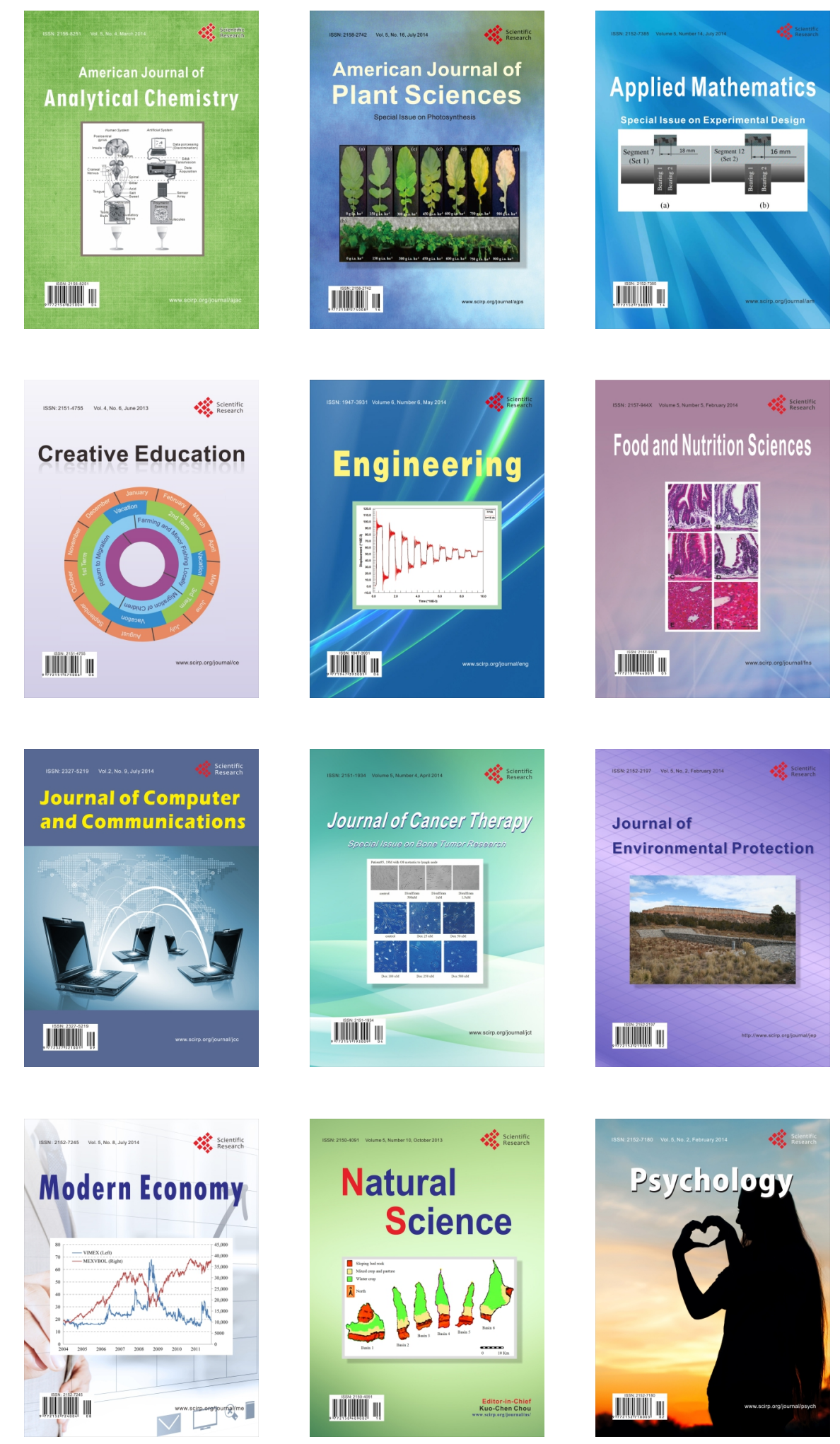